\title{
Engineering Economic Analysis for Feed Gas Cooler (Cold box): a Case of a Gas Processing Complex in Malaysia
}

\author{
Zulkipli Ghazali ${ }^{1, \text { a }}$, M Amin A Majid ${ }^{2}$, and Teh Choon $\mathrm{Chi}^{2}$ \\ ${ }^{1}$ Department of Management \& Humanities, Universiti Teknologi PETRONAS, Bandar Seri Iskandar, \\ 31750 Tronoh, Perak, \\ ${ }^{2}$ Department of Mechanical Engineering, Universiti Teknologi PETRONAS, Bandar Seri Iskandar, \\ 31750 Tronoh, Perak, Malaysia \\ 1,a zulkipli_g@petronas.com.my (Correspondeing author)
}

\begin{abstract}
This study examine the economic feasibility of a proposal to replace an existing Feed Gas Cooler (Cold Box) with a new unit in a gas processing complex in Malaysia. Economic justification is essential to make the decision on the feasibility of this undertaking because of the high capital investment. The mathematical model presented in the paper includes net present worth, payback period, rate of return, investment balance analysis, and sensitivity analysis. Critical analyses on four factors of the estimates were done to assess their influence on the overall economic justification of the proposal. The results indicate an acceptable return on investment. However, the proposal is susceptible to the variation in demand of the Feed Gas Load.
\end{abstract}

Keywords: Feed gas cooler; payback period; present worth analysis (PW); ROR; investment balance; sensitivity analysis; Malaysia.

\section{Introduction}

Investment in engineering project must be viable technically and economically. The decision to invest has financial implication to the scarce resources of a company throughout the life cycle of the project. Therefore, applying economic principles to engineering project evaluation is central $[1,2,3]$.

This paper discusses the economic viability of a proposal to change one unit Feed Gas Cooler (Cold box) with a new Cold box at Gas Processing integrated facility in Malaysia. The alternative Cold box offers a number of operational and technical benefits namely:

- Reduction in the frequency of yearly shutdown. The existing feed gas stream unit experienced frequent blockages, resulting in pressure drop, high cost of maintenance and lengthy shutdown and production losses.

- The new Cold box with additional features offers high reliability, effectiveness and better pressure drop monitoring system.

Nevertheless, final decision on the suggested investment is primarily depends on the engineeing economic analysis and utilization of the different models including investment balance analysis, sensitivity analysis, rate of return, payback period and after tax economic analysis. 


\section{Problem Statement}

Each plant in the gas processing complex is installed with a unit of cold box at the low temperature separation unit (LTSU). LTSU extracts the ethane and heavier components from the feed gas using a combination of propane refrigeration cross heat exchange of process streams and gas expansion followed by a de-methanizer column. The fractionation of the feed gas takes place in the demethanizer which has the function of recovering most ethane and heavier components whilst rejecting lighter components to sales gas. The cold box operates as pre-cooling system for the feed gas in LTSU to reduce the water load on the molecular sieve dehydrators. Upon exiting the cold box, the feed gas enters the warm separator at a temperature between $-22^{\circ} \mathrm{C}$ to $-18^{\circ} \mathrm{C}$.

The cold box capacity at maximum plant load is $680 \mathrm{MT} / \mathrm{H}$. It was commissioned in 1998 . However, after 10years in service it started to experience high pressure drop due to blockage of feed gas stream. The pressure drop keeps increasing over the years despite continuous effort to reduce it to the recommended design condition. Among the efforts are thawing and methanol injection to reduce hydrate, back puffing to remove dust and chemical cleaning. Since 2011, periodic shutdowns ( 2 times per year) for maintenance were carried out for this purpose. The company has to spend approximately RM 19.4mil/year for this purpose.

In the effort to increase the operational and cost efficiency of its operation, the organization needs to replace the existing cold box with a new Feed Gas Cooler (Cold box) from KOBELCO, Japan. The New Cold box has similar capacity (maximum operating capacity $680 \mathrm{MT} / \mathrm{Hr}$ at discharge temperature of $-20^{\circ} \mathrm{C} \pm-2^{\circ} \mathrm{C}$ ). The New Cold box has additional features such as individual pressure drop monitoring system on the four inlet streams and strainers. It has the ability to provide advance warning to prevent further blockages at the cold box. The New Cold box cost RM 36.12 Mil per unit that includes shipment, installation, catalyst and basic engineering design. The existing cold box can be sold for RM 3 Mil. The new cold box capacity is $680 \mathrm{MT} / \mathrm{Hr}$ operating at 8000 hours a year and could process a total annual feed gas production of 5.44 million metric tonne. The annual income is estimated at RM 136 Mil. On the other hand, the existing cold box capacity is $650 \mathrm{MT} / \mathrm{Hr}$. The annual income is estimated at RM 130 Mil.

With the above mentioned background, this paper will highlight the analysis performed to determine the economic justification of the proposal in ensuring the investment add value to the shareholders' fund.

\section{Mathematical Model}

In general there are four types of models used in economic analysis namely visual models, mathematical models, empirical models, and simulation models. This paper highlights the mathematical model used to evaluate the feasibility of the cold box replacement proposal $[4,5,6]$. The mathematical models have two functions. Firstly, it simplifies the financial estimates of the proposed project, and secondly it provides the basis of decision making based on the criteria of selection. The models are delineated below.

\subsection{Net Present Worth (PW)}

Discount future amounts of the estimated cash flows to the present using the minimum attractive rate of return over the appropriate study period:

$$
P W=\sum_{k=0}^{N} F_{k}(1+i)^{-k}
$$




\subsection{Discounted Payback Period}

Discounted payback period shows the liquidity of investment to measure how immediate an investment can be recovered.

Here, Discounted payback period which is denoted with $\theta$ (where $\theta \leq N$ ) is calculated by considering time value of money.

$$
\sum_{k=1}^{\theta}\left(R_{k}-E_{k}\right)-I \geq 0
$$

Note: Usually, a project is considered justifiable if the payback period is $\leq 3$ years.

\subsection{Rate of Return (ROR) Analysis}

Rate of return which is also referred to as discounted cash flow, investor's method or profitability index equates the equivalent work of an alternative's cash inflows (receipts or savings) to equivalent work of cash outflows (expenditures).

$$
P W=\sum_{k=0}^{N} R_{k}\left(P / F, i^{\prime} \%, k\right)-\sum_{k=0}^{N} E_{k}\left(P / F, i^{\prime} \%, k\right)=0
$$

Note: If i' > MARR, the alternative is acceptable

\subsection{Investment Balance Analysis}

Investment balance plots the unrecovered balances tied up in a project and illustrates the recovery of capital over the project's life-cycle. Apart from a mechanism of control, it conveys many essentials facts including discounted payback period and net future worth of the investment.

\subsection{Sensitivity Analysis}

The preceding analysis uses estimates of parameters' future value. Certainly there are some degrees of inaccuracy that can lead to uncertainty in the decision. The effect of the variations in the estimates can be determined using sensitivity analysis. The factor of concerned that is made independent of the other factors in the estimates is varied one at a time. The impact of variation of this factor on the overall economics of the investment proposal can be estimated and mitigative actions can be planned.

\section{Results and Discussion}

\subsection{Investment and Annual Costs}


The identified costs for the present project include Procurement and Installations for Feed Gas Cooler from Japan (RM36.12 mil), Decommissioning of the existing cold box (RM 2 mil), Annual Maintenance Cost of New cold box (RM 0.3 mil) and Annual Maintenance Cost of Old cold box if kept for operating another 10years (13.4 mil).

The annual maintenance of the New cold box include the cost for the annual inspection, crane lifting, manual labor cleaning for the feed gas stream's strainer cleaning of the cold box package, and nondestructive testing (NDT). The annual maintenance cost of the old cold box is high since it has been in service for 10 years. The existing cold box if kept for further operation requires extra maintenance works and downtimes for thawing and methanol injection to reduce hydrate, back puffing to remove dust and chemical cleaning.

\subsection{Estimates of Revenues}

The estimated revenues for the present proposal include Market value of the old cold box (RM3 mil), annual revenue from new cold box Feed Gas production (RM 136 mil), and annual revenue based on existing cold box Feed Gas production (RM130 mil).

\subsection{Cash flows}

The cash flows estimates throughout the life-cycle of the proposal include initial cost of new cold box (RM36.12 mil), de-commissioning cost of old cold box (RM 2 mil), annual operating cost of new cold box (RM 0.3 mil), annual operating cost of old cold box (RM13.4 mil), market value of old cold box (RM3 mil), new cold box Feed Gas production (RM 136 mil), and annual revenue based on existing cold box Feed Gas production (RM130 mil).

\subsection{Net Present Worth}

Net Present Worth (PW)

$$
\begin{aligned}
\mathrm{PW} & =\mathrm{RM}[(-36.12 \mathrm{mil}-2 \mathrm{mil}+3 \mathrm{mil})+19.4 \mathrm{mil}(\mathrm{P} / \mathrm{A}, 10 \%, 10)-0.3 \mathrm{mil}(\mathrm{P} / \mathrm{A}, 10 \%, 10)] \\
& =\mathrm{RM} 82.25 \mathrm{mil}
\end{aligned}
$$

Since PW ( $\mathrm{i}=\mathrm{MARR}=10 \%$ ) is positive, therefore, this project is economically justified.

Note: $* \mathrm{MARR}=10 \%$ based on the weighted average cost of capital (WACC) of the organization is $10 \%$.

\subsection{Discounted Payback Period}

The discounted payback calculation shows the company needs three years to recover the initial investment at the stated minimum attractive rate of return of $10 \%$ per annum. Based on the company's standard of practice, the proposal is desirable.

\subsection{Rate of Return (ROR) Analysis}

The ROR determines the rate of return that equates the equivalent worth of incomes (receipts or savings) to the equivalent worth of disbursements (costs and expenditures). The ROR equation is set up using present worth method as follows:

$$
\begin{aligned}
& \Sigma \mathrm{PW}=0 \\
& \quad 0=\mathrm{RM}[(-36.12 \mathrm{mil}-2 \mathrm{mil}+3 \mathrm{mil})+19.4 \mathrm{mil}(\mathrm{P} / \mathrm{A}, \mathrm{i} \%, 10)-0.3 \mathrm{mil}(\mathrm{P} / \mathrm{A}, \mathrm{i} \%, 10)]
\end{aligned}
$$

By interpolation, $\Sigma \mathrm{PW}=0$, when $\mathrm{i}=54 \%$

Note: * The practice of the organization to select any project for investment must have the IRR greater than $30 \%$. Thus, this project is economically justified. 


\subsection{Investment Balance Diagram Analysis}

As shown in Figure 1, investment balance diagram indicates that the proposed investment is fully recovered at the end of third year. Since the proposal has negative investment balance, therefore, exposure of loss is low till end of third year. The future worth of the project is RM 213.31million. The investment balance diagram has shown additional information to further support the economic justification of the proposal.

Figure 1 Investment Balance Diagram

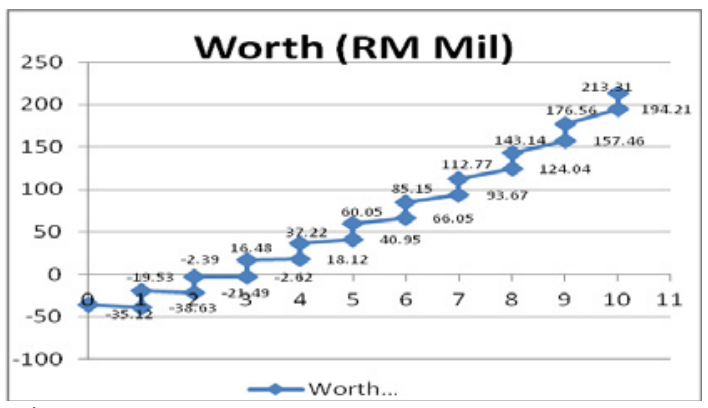

\subsection{Sensitivity Analysis}

The sensitivity analysis [7] was done using spider plot as illustrated in Figure 2. The sensitivity of the projects was evaluated between $-60 \%$ and $+60 \%$ for the net revenue gain, capital investment, salvage value, and operating cost.

Figure 2 Sensitivity Graph

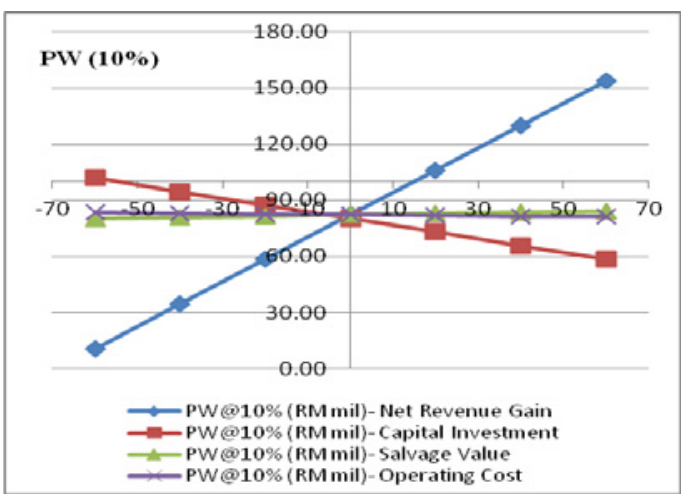

Example of formula used to determine the sensitivity of the proposal towards variations in income estimates:

\section{PW@ 10\% (RM Mil) - Varying "Net Revenue Gain":}

$\mathrm{PW}(10 \%)=\mathrm{RM}[(-36.12 \mathrm{mil}-2 \mathrm{mil}+3 \mathrm{mil})+19.4 \mathrm{mil}(\mathrm{P} / \mathrm{A}, 10 \%, 10)[1 \pm p \% / 100 \%]-0.3 \mathrm{mil}$ $(\mathrm{P} / \mathrm{A}, 10 \%, 10)]$

The sensitivity plot illustrated by Figure 2 shows the relationships of the proposal's present worth to variations in the estimates of net revenue, capital investment, salvage value, and operating costs respectively. The gradient of the lines indicate the degree of sensitivity (the steeper the curve, the more sensitive the present worth is to the factor). Obviously, the proposal is quite sensitive to the variation of the net revenue gain of Feed Gas production if operate at nameplate capacity. However, the proposal is not sensitive to deviations in the estimates of capital investment, salvage value and cost of operation. 


\section{Conclusion}

This paper has highlighted various mathematical models that can be employed to determine the economic justification of engineering investment proposal to replace existing Feed Gas Cooler (Cold box) with new Cold box. Apart from being a decision making tool, the results from the economic analysis can be used as a medium of communication to the project stakeholders on the feasibility of the investment.

Based on the evaluation, the investment is feasible to meet the minimum MARR of $10 \%$ based on the WACC of the company. The ROR of $54 \%$ per year signifies the robustness of the proposal. The discounted payback of three years indicates that the project has low level of uncertainty. The analysis has shown that the proposal is sound and will be able to add value to the shareholders' fund. The proposed investment is able to eliminate the raising operating cost and production losses as a result of worsening condition of the existing cold box. This is a viable alternative to sustain the operation of the company. Notwithstanding the above, other non-economic factors relating to Health, Safety and Environment (HSE) should not be overlooked.

\section{References}

1. G. S. D. Schaber, D. I. Gerogiorgis, R. Ramachandran, J. M. B. Evans, P. I. Barton, and B. L. Trout, "Economic Analysis of Integrated Continuous and Batch Pharmaceutical Manufacturing: A Case Study", Ind. Eng. Chem. Res., 50, pp. 10083-10092 (2011).

2. J. Apt, A. Newcomer, L. B. Lave, S. Douglas, and L. M. Dunn, "An Engineering-Economic Analysis of Syngas Storage", National Energy Technology Laboratory, http://www.netl.doe.gov/energy-analyses/pubs/Final\%20Report-\%20EngineeringEconomic\%20Analysis\%20of\%20Syngas\%20Storag.pdf dated $14^{\text {th }}$ September 2011, (2008).

3. O. Bailey, B. Ouaglal, E. Bartholomew, C. Marnay, and N. Bourassa, "An Engineering-Economic Analysis of Combined Heat and Power Technologies in a $\mu$ Grid Application", http://eetd.lbl.gov/ea/emp/reports/50023.pdf dated 15th September, 2011, (2002).

4. W. G. Sullivan, E. M. Wicks, and C. P. Koelling, Engineering Economy. Pearson Education, Inc., New Jersey (2009).

5. T. G. Eschenbach, Engineering Economy: Applying Theory to Practice. Oxford University Press, Inc., New York, (2003).

6. S. Park,. Fundamentals of Engineering Economics. Pearson Education, Inc., New Jersey, (2004).

7. Amin A. M., Zulkipli G., and Nazri T. S. M. "Techno-economic evaluation on enhancing cogeneration plant capacity: case study of palm oil mill cogeneration plant", J. Appl. Sci., 14, 3, (2014) 